\title{
Human Red Blood Cells Modulate Cytokine Expression in Monocytes/ Macrophages Under Anoxic Conditions
}

\author{
Antonella Antonelli*, Emanuele Salvatore Scarpa and Mauro Magnani \\ Department of Biomolecular Sciences, University of Urbino Carlo Bo, Urbino, Italy
}

In the bone marrow (BM) hematopoietic niche, the oxygen tension is usually very low. Such condition affects stem and progenitor cell proliferation and differentiation and, at cellular level regulates hematopoietic growth factors, chemokines and adhesion molecules expression. In turn, these molecules affect the proliferation and maturation of other cellular components of the niche. Due to the complexity of the system we started the in vitro investigations of the IL-6, IL-8, TNF $\alpha$ cytokines expression and the vascular endothelial growth factor (VEGF), considered key mediators of the hematopoietic niche, in human

OPEN ACCESS

Edited by:

Sandro Malacrida,

Eurac Research, Italy

Reviewed by:

Paolo Laveder,

University of Padua, Italy

Giulio Ceolotto,

University of Padua, Italy

*Correspondence:

Antonella Antonelli antonella.antonelli@uniurb.it

Specialty section: This article was submitted to Red Blood Cell Physiology, a section of the journal

Frontiers in Physiology

Received: 23 November 2020 Accepted: 22 January 2021 Published: 18 February 2021

Citation:

Antonelli A, Scarpa ES and Magnani M (2021) Human Red Blood Cells Modulate Cytokine Expression in Monocytes/Macrophages Under Anoxic Conditions.

Front. Physiol. 12:632682. doi: 10.3389/fphys.2021.632682 macrophages and macrophage cell line. Since in the niche the oxygen availability is mediated by red blood cells (RBCs), we have influenced the anoxic cell cultures by the administration of oxygenated or deoxygenated RBCs (deoxy RBCs). The results reported in this brief paper show that the presence of RBCs up-regulates IL-8 mRNA while IL-6 and VEGF mRNA expression appears down-regulated. This does not occur when deoxy RBCs are used. Moreover, it appears that the administration of RBCs leads to an increase of TNF $\alpha$ expression levels in MonoMac 6 (MM6). Interestingly, the modulation of these factors likely occurs in a hypoxia-inducible factor- $1 \alpha(\mathrm{HIF}-1 \alpha)$ independent manner. Considering the role of oxygen in the hematopoietic niche further studies should explore these preliminary observations in more details.

Keywords: hypoxia, macrophages, red blood cells, $\mathrm{pO}_{2}$ variation, cytokine expression modulation

\section{INTRODUCTION}

The bone marrow (BM) is a tissue of complex architecture that is organized into a hematopoietic cell compartment and the stroma, which is mainly composed of fibroblasts, adipocytes, nerves, and the BM's vascular system (Morrison and Scadden, 2014; Tamma and Ribatti, 2017). In BM thin-walled sinusoidal vessels are highly specialized capillaries with a discontinuous basement membrane and fenestrations that facilitate trafficking of cells and soluble factors between the blood and the BM compartment. This vasculature provides not only a route for mature hematopoietic cells to the peripheral circulation but also a place where hematopoietic progenitors differentiate and set the stage for full reconstitution of hematopoiesis, which maintains in the peripheral blood a constant level of the different blood cell types and components (erythrocytes granulocytes, platelets, lymphocytes, etc.). Oxygen tension $\left(\mathrm{pO}_{2}\right)$ is an important determinant 
of hematopoietic stem and progenitor cell (HSPC) proliferation and differentiation. Thus, understanding the impact of the $\mathrm{BM}$ architectural organization on $\mathrm{pO}_{2}$ levels in extravascular hematopoietic tissue is an important biophysical problem. If oxygen concentration in the atmosphere is normally $21 \%$, corresponding to $159 \mathrm{mmHg}$, in tissues $\mathrm{O}_{2}$ levels span from 150 to $20-70 \mathrm{mmHg}$ (2.5-9\% oxygen), and markedly lower levels $(<1 \%$ oxygen) have been described in necrotic tissue sites. The condition of reduced oxygen tension is defined as hypoxia. Reduced oxygen tension $\left(\mathrm{pO}_{2} 38 \mathrm{~mm} \mathrm{Hg}, 5 \% \mathrm{O}_{2}\right)$ has been shown to enhance the production of erythroid, megakaryocytic, and granulocytic-monocytic progenitors in vitro. In fact, due to the inaccessibility of bone marrow to direct noninvasive oxygen measurements, some authors have used mathematical modeling of $\mathrm{pO}_{2}$ distributions in the bone marrow and speculated that stem cells are located at the region with very low $\mathrm{pO}_{2}$ levels (almost anoxic) because this prevents oxygen radicals from damaging these important cells (Chow et al., 2001). Moreover, previous studies have suggested that local oxygen tension determines the location of hematopoietic stem cells (HSCs) in the BM compartment (Parmar et al., 2007; Spencer et al., 2014).

During megakaryopoiesis, megakaryocytes (Mks) differentiate from HSCs and localize in the proximity of the sinusoid blood vessels where they extend long filaments called proplatelets into the blood vessel lumen through the vascular endothelium where platelets, stemming from their terminal ends, are released into the bloodstream by blood shear forces. Despite their critical role in many physiological functions, little is known about the molecular mechanisms involved in platelet production from Mks, or about the pathogenesis of platelet disorders. The characteristics of the environment surrounding Mks play a fundamental role in the regulation of megakaryopoiesis. However, the study of the bone marrow microenvironment in vivo has been hampered because of the diffuse three dimensional (3D) nature of its structure and complexity within the bone cavity, especially in humans where invasive approaches are not possible; for this reason, some emerging strategies to obtain information are based on the use of relevant 3D models that offer a scientific approach to mimic and control the physiology of human bone marrow environment within which cells live (Di Buduo et al., 2015; Abbonante et al., 2020). Several authors have contributed in defining niches and mobilization pathways for HSPCs, including the identification of several cell types involved such as osteoblasts, adventitial reticular cells, endothelial cells, monocytic cells, and granulocytic cells and the main factors that anchor HSPCs in the niche and/or induce their quiescence such as vascular cell adhesion molecule (VCAM)-1, CD44, hematopoietic growth factors, e.g., stem cell factor (SCF), chemokines including IL-12 and IL-8 (Richter et al., 2017). A number of cytokines, growth factors, and non-protein metabolites, such as lipids or ions have been demonstrated to play pivotal roles in bone marrow vascular niche regulation (Zhang et al., 2019). Moreover, there is evidence that macrophage cells play an essential role in the maintenance and regulation of BM vascular niche function by secreting large quantities of several molecules with hematopoietic activity, including interleukins that can affect hematopoietic cells. It has been reported that resting macrophages regulate the maturation of Mks and platelet biogenesis releasing mainly IL-8 (D'Atri et al., 2011). It is also known that some sirtuin enzymes, depending by $\mathrm{NAD}^{+}$binding can mediate the transcriptional activation of IL-8 and regulate hypoxia-inducible factor- $1 \alpha$ (HIF-1 $\alpha$ ) stabilization which is routinely used to screen for hypoxia (Wang et al., 1995; Bauer et al., 2012; Di Girolamo et al., 2013; Edatt et al., 2020). Under normoxic conditions, the $\alpha$ subunit of HIF-1 is hydroxylated by prolyl hydroxylases (PHDs), recognized by the protein product of the von-Hippel-Lindau (VHL) gene, ubiquitinated and degraded by the proteasome (Magnani et al., 1994; Huang et al., 1998; Loboda et al., 2012). In hypoxia the PHDs are not active and consequently HIF-1 $\alpha$ is not degraded but can translocate to the nucleus, and can dimerize with the $\beta$ subunit. The heterodimeric transcription factor induces the transcription of genes mediating cellular adaptation to a low oxygen environment. Macrophages in hypoxic condition also respond with increased IL-6 production that can affect both stromal and hematopoietic cells, for example stimulating $\mathrm{Mk}$ growth and maturation in vitro as well as increasing Mk ploidy (Murdoch et al., 2005; Tanaka et al., 2014). Expression of also VEGF by macrophages is markedly increased by exposure to hypoxia in vitro (Tamura et al., 2020). However, the precise role of macrophages in the regulation of human megakaryo/thrombopoiesis is largely unknown.

In the context of the elucidation of the basic mechanisms of intracellular cross-talks between the different cell components of vascular niche we report preliminary data collected during an in vitro study performed with an anoxic cell model about the modulation of the expression of specific cytokines.

\section{MATERIALS AND METHODS}

\section{Cell Cultures and Reagents}

Human monocyte-derived macrophages were prepared from buffy coats provided by healthy adult volunteers at the Blood Transfusion Center of "S. Maria della Misericordia" Hospital in Urbino (PU), Italy. All volunteers signed an informed consent form before donation. Macrophages were prepared by density gradient separation using Lymphoprep solution (specific density, 1.077; Axis-Shield PoC AS, Oslo, Norway). Each experiment was performed with macrophages obtained from a single buffy coat $(\sim 50 \mathrm{ml})$ derived from a single donor. The buffy coat was centrifuged at $150 \mathrm{~g}$ for $15 \mathrm{~min}$ at room temperature to eliminate platelets and serum. The pellet was diluted 1:2 with phosphate buffered saline (PBS) and overlaid on Lymphoprep solution (2:1 ratio) and centrifuged at $300 \mathrm{~g}$ for $30 \mathrm{~min}$. The ring of peripheral blood mononuclear cells (PBMCs), was isolated, washed twice with PBS and resuspended in RPMI medium supplemented with $10 \%(\mathrm{v} / \mathrm{v})$ heat-inactivated FBS, $100 \mathrm{U} / \mathrm{ml}$ penicillin, $100 \mu \mathrm{g} / \mathrm{ml}$ streptomycin and $2 \mathrm{mM}$ L-glutamine. Essentially, the human macrophages have been obtained from monocytes through their distinguishable ability for plastic adherence. After $24 \mathrm{~h}$ in culture in $25 \mathrm{~cm}^{2}$ flasks (Cell Star, greiner bio-one), at $37^{\circ} \mathrm{C}$ in a humidified $5 \% \mathrm{CO}_{2}$ atmosphere, non-adherent cells were removed 
by rinsing with cell medium in order to isolate adherent monocytes. The culture media was renewed every 2 days and monocyte-derived macrophages were used at 7 th day of adherence. Experiments were performed with $1.5 \times 10^{6}$ macrophages for each condition. MonoMac 6 (MM6) cells, derived from human acute monocytic leukemia (Ziegler-Heitbrock et al., 1988) were obtained from DMSZ GmbH (Braunschweig, Germany) and cultured in $25 \mathrm{~cm}^{2}$ flasks at a density of $0.5-1 \times 10^{6} \mathrm{cells} / \mathrm{ml}$ as described in (Palma et al., 2011). Approximately $2.5 \times 10^{6}$ MM6 cells were used for each experimental condition. MM6, macrophages and RBCs were exposed to anoxia by using an Hypoxia Incubator Chamber (Chamber for generation of a hypoxic environment for tissue culture, StemCell Technologies) flushed with the appropriate $95 \% \mathrm{~N}_{2}$ and $5 \% \mathrm{CO}_{2}$ gas mixture for 15 min to reach anoxia condition and placed at $37^{\circ} \mathrm{C}$ in a humidified incubator $95 \%$ air, $5 \% \mathrm{CO}_{2}$. In our experiment design, MM6 cells were treated for 2, 4, 6, 8, 21, and $24 \mathrm{~h}$ and human macrophages for 2, 4, 6, and $24 \mathrm{~h}$. Normoxic cells were also maintained in the incubator as control samples. Moreover, in comparison to anoxic condition, some cell samples were also treated with $\mathrm{CoCl}_{2}$ (Sigma Aldrich), a widely used chemical hypoxia mimetic model; $\mathrm{CoCl}_{2}$ was diluted in complete cell culture media prior to cell stimulation. It has been demonstrated that $\mathrm{CoCl}_{2}$ induces hypoxia-regulated genes by stabilizing HIF-1 $\alpha$ in normoxia (Yuan et al., 2003).

The human RBCs were prepared from blood collected in heparinized tubes and derived from healthy adult volunteers of Transfusion Center who signed an informed consent. For all the experiments, blood derived from six donors was used. The blood from a single volunteer was used to prepare RBCs for each experiment. RBCs were isolated as already reported (Antonelli et al., 2020) and resuspended in the same buffer at $10 \%$ hematocrit before being deoxygenated or not and administered to anoxic MM6 and human macrophages cells for $3 \mathrm{~h}$. After $3 \mathrm{~h}$ of incubation with RBCs, the MM6 cells were packed by centrifugation at $900 \mathrm{~g}$ and RBCs present in the pellet were lysed with sterile distilled water for $3 \mathrm{~min}$. Immediately afterwards, MM6 cells were resuspended in phosphate buffer saline (PBS) and washed twice by centrifugation to eliminate hemoglobin released from RBCs. Instead, RBCs were removed from adherent human macrophages by three washes with PBS buffer. Total cell extracts obtained using specific lysis buffers were processed for real-time quantitative PCR (RT-qPCR) analysis of IL-6, IL-8, TNF $\alpha$, VEGF, and hypoxia-inducible factor- $1 \alpha$ (HIF- $1 \alpha)$ mRNA expression or to detect HIF-1 $\alpha$ protein by Western blotting analysis.

\section{Western Blotting Analysis}

Cells were lysed in buffer containing Urea $6 \mathrm{M}$, Tiourea $2 \mathrm{M}$, DTT 100 mM, Tris-HCl 30 mM, pH 7.5, Triton 1\% and glycerol 9\% supplemented with protease inhibitors (cComplete Mini; Roche, Basel, Switzerland); lysates were boiled within $7 \mathrm{~min}$, sonicated twice at 100 Watt for $10 \mathrm{~s}$ and cleared by centrifugation at $15,000 \times g$ for $10 \mathrm{~min}$, then the supernatants were recovered. The proteins determined by using Bio-Rad Protein Assay (Bio-Rad, Hercules, CA, United States) were resolved by $8 \%$ SDS polyacrylamide gel electrophoresis (SDS-PAGE) and afterward transferred onto nitrocellulose membrane (100 V, $70 \mathrm{~min}$ at $\left.4^{\circ} \mathrm{C}\right)$. The blots were probed with the following primary antibodies: anti-HIF-1 $\alpha$ (\#14179, monoclonal, recognizing amino acidic residues surrounding Lys460 that is codified by the exon 10 of HIF1A CDS ${ }^{1}$ ) from Cell Signaling Technology (Danvers, MA, United States); anti-Lamin A/C (\#sc-376248, monoclonal) from Santa Cruz Biotechnology (Dallas, TX, United States); anti- $\beta$-actin (\#VMA00048, monoclonal) from Bio-Rad (Hercules, CA, United States). Immunoreactive bands were detected by horseradish peroxidase (HRP)-conjugated secondary antibodies (Bio-Rad). Peroxidase activity was detected with the enhanced chemiluminescence detection method (WesternBright ECL, Advasta, Menlo Park, CA, United States) using the ChemiDoc MP Imaging System (Bio-Rad). Quantification of the protein bands has been performed using Image Lab analysis software version 5.2.1 (Bio-Rad).

\section{Real-Time Quantitative PCR}

Gene-specific expression analyses were performed as already reported (Scarpa et al., 2020). Fluorescence intensity of each amplified sample was measured with an ABI PRISM 7500 Sequence detection system (Applied Biosystems, Foster City, CA, United States). All measurements were performed at least in triplicate and reported as the average values \pm standard deviation of the mean (mean \pm SD). Target gene values were normalized with B2M mRNA measurements, and expression data were calculated according to the $2^{-\Delta \Delta \mathrm{CT}}$ method. Primers were designed using Primer 3 Plus, and their sequences are: IL8-F: 5'-TTGCCAAGGAGTGCTAAAGAA-3'; IL8-R: 5'-GCC CTCTTCAAAAACTTCTCC-3'. IL6-F: 5'-AATTCGGTACATC CTCGACGG-3'; IL6-R: 5'-GGTTGTTTTCTGCCAGTGCC-3'. VEGF-F: 5'-TCACAGGTACAGGGATGAGGACAC-3'; VEGF-R: 5'-CAAAGCACAGCAATGTCCTGAAG-3'. B2M-F: 5'- GCCTG CCGTGTGAACCAT-3'; B2M-R: 5'-CATCTTCAAACCTCCATG ATGCT-3'. TNF $\alpha$-F: 5'-GCCCAGGCAGTCA-GATCATCTTC-3'; TNF $\alpha$-R: 5'-TGCCCCTCAGCTT-GAGGGT-3'. HIF1A-F: 5'-TCTG GGTTGAAACTCAAGCAACTG-3'; and HIF1A-R: 5'-CAACCGG TTTAAGGACACATTCTG-3'.

\section{Statistical Analysis}

The data were expressed as mean \pm SD of three independent experiments. Student's $t$-test and ANOVA test performed with Past Software version 3 were used for statistical analysis of the data; differences between groups were considered statistically significant when $p<0.05$.

\section{RESULTS AND DISCUSSION}

Human peripheral blood macrophages and MM6 cells (showing functional features of mature blood monocytes), were considered as cell models to study the effect of anoxia exposure on the expression of some biological factors with a regulatory role in the environment of BM vascular niche. Recent studies show

${ }^{1}$ https://www.ncbi.nlm.nih.gov/nuccore/NM_001530.4 
that macrophages respond rapidly to the hypoxia condition by altering their expression of a wide array of genes. Among the various roles played by macrophages, they are also responsible for regulating tissue oxygenation by influencing the formation of new blood vessels and modulating vascular permeability. Notably, in response to hypoxia, macrophages have been shown to induce proangiogenic molecules such as VEGF, and IL-8. Some studies have already shown that HIFs, but not NF-kB, are important transcriptional effectors regulating the responses of macrophages exposed to $18 \mathrm{~h}$ hypoxia (Fang et al., 2009). It is currently accepted that resting macrophages, which are relevant components of the BM stroma, release soluble factors that promote megakaryocyte growth, proplatelet production, and platelet release (D'Atri et al., 2011). Here, we investigated the cellular response to anoxia stimulus obtained by using a hypoxic incubator chamber and a gas mixture of $95 \% \mathrm{~N}_{2}$ and $5 \% \mathrm{CO}_{2}$. Firstly, the results were compared to those obtained with the chemical agent $\mathrm{CoCl}_{2}$ which has been shown to mimic the hypoxic conditions in cells by stabilizing the transcription factor HIF- $1 \alpha$. When $\mathrm{CoCl}_{2}$ is added to the cell culture, the hydroxylation activity of PHDs is inhibited, therefore HIF-1a protein is not degraded through the ubiquitin/proteasome pathway (MunozSànchez and Chanez-Càrdenas, 2019). Figure 1 shows a representative time-course experiment performed with MM6 cell model exposed to anoxia (Figures 1A-C) and to $100 \mu \mathrm{M}$ $\mathrm{CoCl}_{2}$ (Figures 1D-F). When $\mathrm{CoCl}_{2}$ is added to the cell culture, the hydroxylation activity of PHDs is inhibited, therefore HIF- $1 \alpha$ protein is not degraded through the ubiquitin/proteasome pathway. mRNA levels of some cytokines such as IL-8, IL-6, and VEGF have been measured. Cells maintained in normoxia $\left(21 \% \mathrm{O}_{2}\right)$ for the same time period of treatment were used as controls. Under anoxia, an increase of IL-8 mRNA levels (Figure 1A) was found within the $24 \mathrm{~h}$ of experimental design; IL- 8 expression levels reach values that are about 7 -folds higher than controls; the highest expression values are at 4 and $24 \mathrm{~h}$ of incubation ( 4 h: $3.21 \pm 0.93, p=0.004 ; 24$ h: $7.62 \pm 2.24, p=0.015$ ) similarly to what happens with the $\mathrm{CoCl}_{2}$ treatment (Figure 1D) performed in the same time range ( $4 \mathrm{~h}: 6.81 \pm 1.41, p=0.025$; 24 h: $9.10 \pm 3.64, p=0.018)$. Moreover, IL-6 expression levels significantly increase after $24 \mathrm{~h}$ of anoxia exposure (4.81 \pm 0.70 , $p=0.029$; Figure 1B), whereas in $\mathrm{CoCl}_{2}$-treated cells the IL-6 levels increase already from $2 \mathrm{~h}$ with a peak of expression at $4 \mathrm{~h}(15.32 \pm 0.44, p<0.001)$, Figure 1E. Furthermore, VEGF expression levels remarkably increase only after $21 \mathrm{~h}$ and $24 \mathrm{~h}$ anoxia treatment (Figure 1C), with a peak at $21 \mathrm{~h}(5.80 \pm 1.10$, $p=0.003$ ) and also after $\mathrm{CoCl}_{2}$ treatment (Figure 1F), with a maximum peak at $8 \mathrm{~h}(2.90 \pm 0.37, p=0.046)$. At the same time, we have evaluated by western blot analyses the content of HIF-1 $\alpha$ protein in cell lysates of MM6 cells exposed to anoxia (Figure 1G) and $\mathrm{CoCl}_{2}$ (Figure 1H). It is evident that HIF-1 $\alpha$ expression was remarkably induced under anoxic condition after $6 \mathrm{~h}$ of exposure with an increase of the protein levels up to $21 \mathrm{~h}$ followed by a return toward basal levels at $24 \mathrm{~h}$ (Figure 1G, Table 1). Similar results obtained after $\mathrm{CoCl} 2$ treatment are shown in Figure $\mathbf{1 H}$ where the HIF-1 $\alpha$ protein appears in different isoforms (in the range of 75-100 $\mathrm{kDa}$ ), as already described in literature (Monsef et al., 2010),
Figure $1 \mathbf{H}$ and Table 1 . In fact, it is not uncommon to detect protein bands other than at the one expected at $120 \mathrm{kDa}$; different forms of HIF- $1 \alpha$ protein detectable after $\mathrm{CoCl}_{2}$ treatment, have been already described (Rana et al., 2019).

The same experimental design was performed with monocytederived macrophages isolated from human peripheral blood. Figure 2 shows a different response to the anoxia or $\mathrm{CoCl}_{2}$ stimuli with respect to leukemia MM6 cells. After 6 h of anoxia exposure the IL- 8 mRNA level increases of about 4-fold (4.02 \pm 1.16 , $p=0.047$ ) respect to normoxia value (Figure 2A) whereas with $\mathrm{CoCl}_{2}$ treatment the maximum expression occurs at shorter times ( $2 \mathrm{~h} ; 4.43 \pm 1.40, p=0.003$; Figure $2 \mathrm{D}$ ); in both cases the mRNA expression decreases within the $21 \mathrm{~h}$. IL- $6 \mathrm{mRNA}$ expression seems to augment after already $2 \mathrm{~h}$ of $\mathrm{CoCl}_{2}$ (Figure 2E) or anoxia (Figure 2B) treatment reaching values of about 1.5-fold $(1.76 \pm 0.53, p=0.603)$ and 4 -fold $(3.86 \pm 1.05, p=0.041)$ increase, respectively. VEGF expression appears to have a similar trend when macrophages are exposed to both stimuli (Figures $2 \mathrm{C}, \mathbf{F}$ ) which induce a remarkable increase of mRNA levels in the range of $4-6 \mathrm{~h}$ of treatment (peak at $4 \mathrm{~h}$ for anoxia; $8.49 \pm 0.05$, $p<0.001$; peak at $6 \mathrm{~h}$ for $\left.\mathrm{CoCl}_{2}, 5.74 \pm 1.59, p<0.001\right)$.

The results obtained from these analyses are in accordance with literature; for example, it is well known that human macrophages respond to oxygen stress such as an anoxia exposure with augmented production of IL-8 (Metinko et al., 1992; Rydberg et al., 2003).

Western blotting analysis of HIF-1 $\alpha$ protein in the macrophages extracts obtained after anoxia (Figure 2G) and $\mathrm{CoCl}_{2}$ (Figure 2H) stimuli at the indicated times showed increased amounts of the protein, as $200 \mathrm{kDa}$ band, already from the $2 \mathrm{~h}$ of treatment (Table 1 ). HIF- $1 \alpha$ protein can be still detected at $24 \mathrm{~h}$ after anoxia exposure while it decreases at the same time after $\mathrm{CoCl}_{2}$ treatment. After the evaluation of cell response to anoxia stimulus establishing the highest peaks of gene expression of these specific cytokines $(6 \mathrm{~h}$ for human macrophages and $21 \mathrm{~h}$ for MM6 cells), we have in vitro studied the impact of RBCs on these cell lines in order to understand if a variation of $\mathrm{pO}_{2}$ level in anoxic environment could alter or regulate the expression of these soluble factors. In fact, oxygen transport to the hematopoietic niche is mediated by $\mathrm{RBCs}$ and $\mathrm{RBC}$ oxygenation represents more closely the niche oxygen availability rather than the simple oxygen concentration in the tissue cultures.

Figure 3 shows the IL-8, IL-6, VEGF and TNF $\alpha$ mRNA levels obtained after the addition of RBCs at $10 \%$ hematocrit for $3 \mathrm{~h}$ to MM6 (Figures 3A-D) and human macrophage cells (Figures 3E-H), respectively. The data were compared with results obtained after the administration of deoxy RBCs to MM6 cells or human macrophages incubated at the same condition of cells treated with native RBCs. It is evident that a further increase in IL-8 expression levels in anoxic MM6 cells incubated with native RBCs occurs (anoxia $21 \mathrm{~h}+\mathrm{RBCs}$, $14.08 \pm 2.93$ vs. anoxia 21 h; $5.88 \pm 1.92, p=0.048$, Figure 3A), but this treatment did not lead to an increase in IL-6 expression levels, rather to a decrease (anoxia $21 \mathrm{~h}+\mathrm{RBCs} 1.565 \pm 0.62$ vs. anoxia $21 \mathrm{~h}, 2.84 \pm 0.75, p=0.48$, Figure $3 \mathrm{~B})$. Moreover, VEGF mRNA levels significantly decrease (anoxia $21 \mathrm{~h}+\mathrm{RBCs}$ 
A

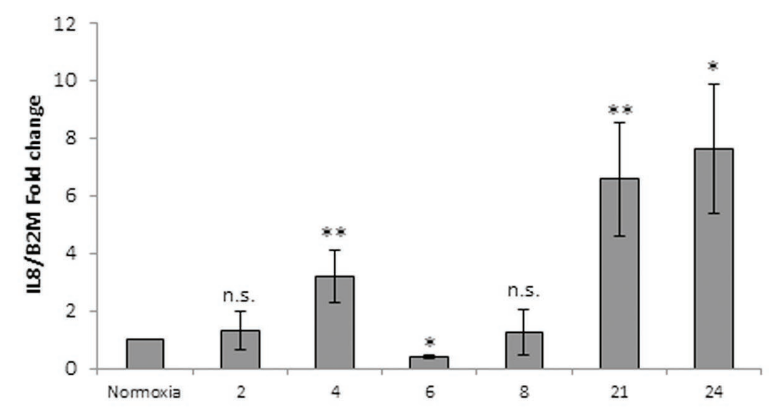

B

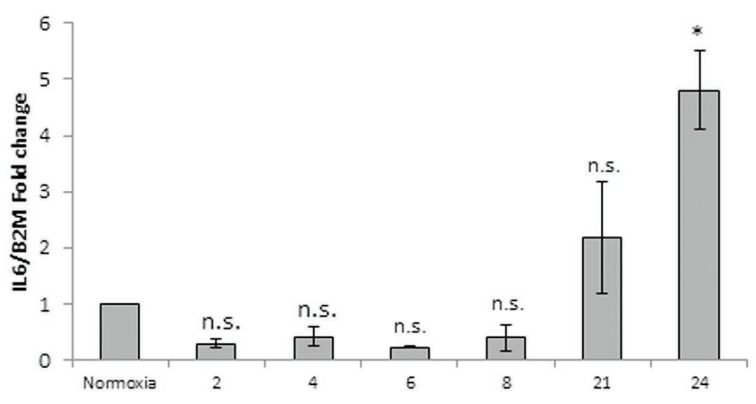

C

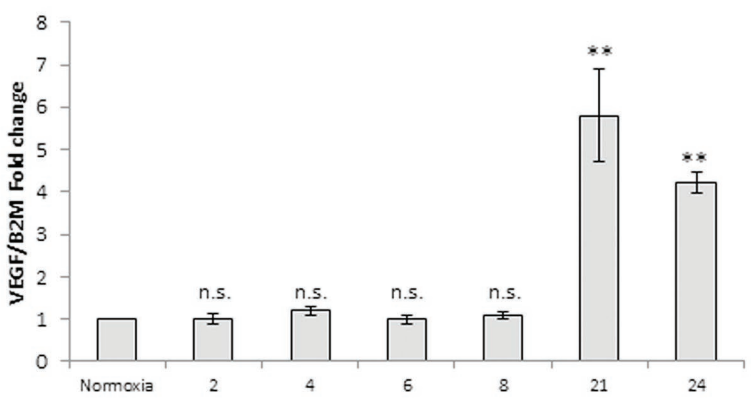

G

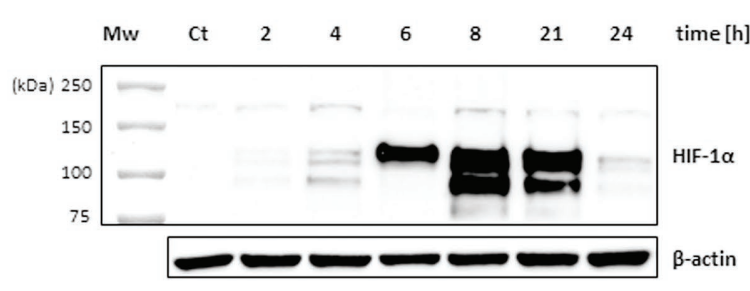

D

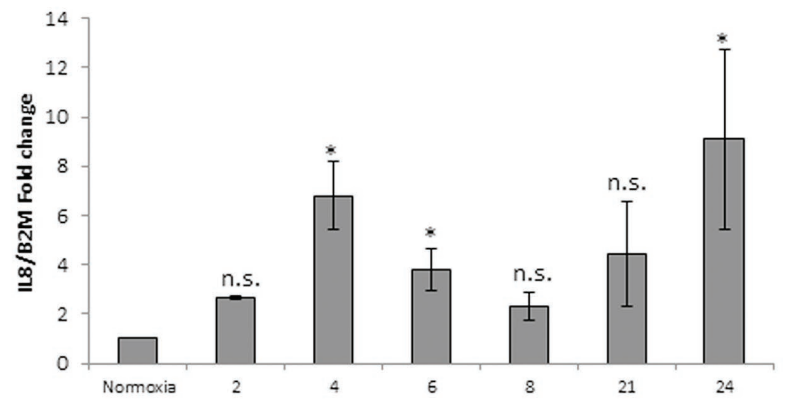

E

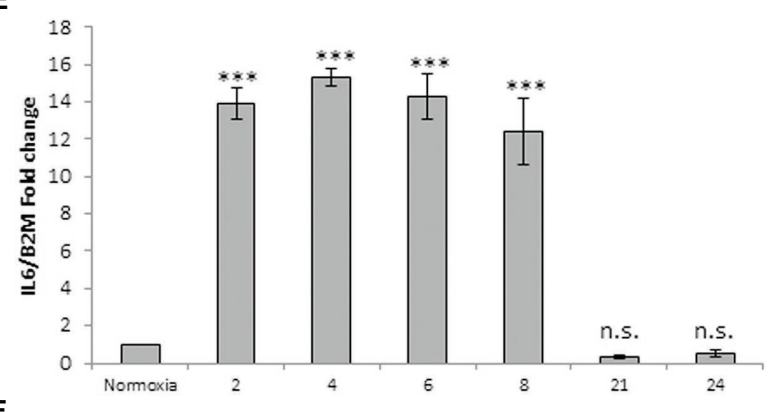

$\mathbf{F}$

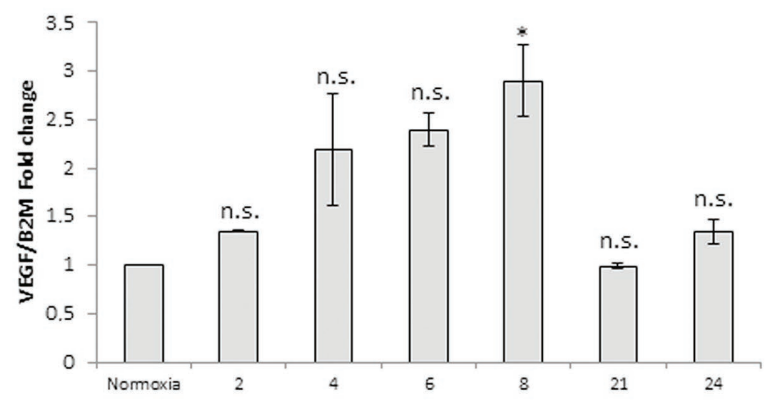

H

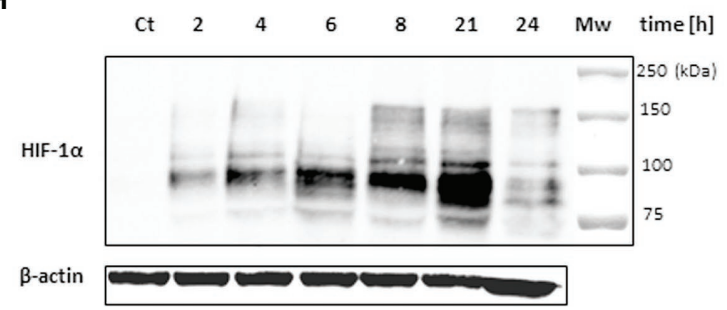

FIGURE 1 | mRNA levels of IL-8, IL-6, and vascular endothelial growth factor (NEGF) in cell extracts of MonoMac 6 (MM6) cells after anoxia (95\% $\mathrm{N}_{2}, 5 \% \mathrm{CO}_{2} ; \mathbf{A - C}$ ) and $100 \mu \mathrm{M} \mathrm{CoCl}_{2}$ (D-F) treatment at different times (hours). Values are expressed as mean $\pm \mathrm{SD} ; n=3,{ }^{*} p<0.05 ;{ }^{* *} p<0.01 ; * * * p<0.001$; n.s., not significant. Western blotting analysis shows the hypoxia-inducible factor- $1 \alpha(\mathrm{HIF-1} \alpha)$ protein in total extracts after anoxia $(\mathbf{G})$ and $\mathrm{CoCl}_{2}(\mathbf{H})$ treatment of $\mathrm{MM} 6$ cells at the indicated times.

$1.525 \pm 0.28$ vs. anoxia 21 h $3.01 \pm 0.35, p=0.004$, Figure 3 C). In addition, the incubation of MM6 cells with deoxy RBCs did not lead to an increase of IL- 6 and VEGF expression levels (for IL-6; anoxia $21 \mathrm{~h}+$ deoxy RBCs $3.52 \pm 0.11$ vs. anoxia $21 \mathrm{~h}, 2.84 \pm 0.75, p=0.56)$. Concerning VEGF mRNA levels, the values decreased when deoxy RBCs were administered to anoxic MM6 (anoxia $21 \mathrm{~h}+$ deoxy RBC $1.19 \pm 0.18$ vs. anoxia $21 \mathrm{~h}, 3.01 \pm 0.35, p=0.007)$ as also after reoxygenation of anoxic cells (anoxia $21 \mathrm{~h}+$ air, $1.05 \pm 0.15$ vs. anoxia $21 \mathrm{~h}, 3.01 \pm 0.35, p=0.039$, Figure $3 \mathrm{C}$ ). In addition, IL-8 mRNA levels appear also decreased after the treatment with deoxy RBCs compared to values obtained with anoxia exposure (anoxia $21 \mathrm{~h}+$ deoxy RBCs $1.23 \pm 0.36$ vs. anoxia $21 \mathrm{~h}$ $5.88 \pm 1.92, p=0.037)$. Moreover, the value of IL-8 mRNA level of anoxic MM6 cells treated with deoxy RBCs was lower than value of cells treated with native RBCs (anoxia $21 \mathrm{~h}+\mathrm{RBCs}$ 
TABLE 1 | Quantification of the HIF-1 $\alpha$ protein bands in the immunoblots reported in Figures 1-3.

\begin{tabular}{|c|c|c|c|c|c|c|c|c|c|c|c|}
\hline Figure 1G & Net Intensity (A.U.) & SD & $p$ value & Figure $1 \mathrm{H}$ & Net intensity (A.U.) & SD & $p$ value & Figure $\mathbf{3 l}$ & Net intensity (A.U.) & SD & $p$ value \\
\hline Control & 0.0016 & 0.0004 & & Control & 0.0006 & 0.0001 & & Control & 0.0246 & 0.0071 & \\
\hline Anoxia $2 \mathrm{~h}$ & 0.0778 & 0.0114 & 0.294 & $\mathrm{CoCl}_{2} 2 \mathrm{~h}$ & 0.0307 & 0.0073 & $0.002^{\star \star}$ & Anoxia $21 \mathrm{~h}$ & 0.2047 & 0.0570 & $0.025^{\star}$ \\
\hline Anoxia $4 \mathrm{~h}$ & 0.3220 & 0.1207 & $0.002^{\star \star}$ & $\mathrm{CoCl}_{2} 4 \mathrm{~h}$ & 0.0810 & 0.0250 & $0.005^{\star \star}$ & Anoxia + RBCs & 0.0544 & 0.0236 & 0.090 \\
\hline Anoxia $6 \mathrm{~h}$ & 3.7122 & 1.4873 & $0.006^{\star \star}$ & $\mathrm{CoCl}_{2} 6 \mathrm{~h}$ & 0.0897 & 0.0250 & $0.003^{\star \star}$ & Anoxia + RBCs deox & 0.1095 & 0.0349 & $0.034^{*}$ \\
\hline Anoxia $8 \mathrm{~h}$ & 6.0074 & 2.7509 & $0.008^{\star *}$ & $\mathrm{CoCl}_{2} 8 \mathrm{~h}$ & 0.1323 & 0.0443 & $0.007^{\star \star}$ & Anoxia + Air & 0.0231 & 0.0121 & 0.648 \\
\hline Anoxia $21 \mathrm{~h}$ & 3.1870 & 1.4013 & $0.006^{\star *}$ & $\mathrm{CoCl}_{2} 21 \mathrm{~h}$ & 0.2883 & 0.1287 & $0.003^{\star *}$ & $\mathrm{CoCl}_{2}$ & 0.4851 & 0.1962 & $0.027^{*}$ \\
\hline Anoxia $24 \mathrm{~h}$ & 0.1643 & 0.0543 & 0.181 & $\mathrm{CoCl}_{2} 24 \mathrm{~h}$ & 0.0303 & 0.0128 & $0.016^{\star}$ & Figure $\mathbf{3} \mathbf{J}$ & Net intensity (A.U.) & SD & $p$ value \\
\hline Figure 2G & Net intensity (A.U.) & SD & $p$ value & Figure $2 \mathrm{H}$ & Net intensity (A.U.) & SD & $p$ value & Control & 0.0011 & 0.0004 & \\
\hline Control & 0.0065 & 0.0022 & & Control & 0.1348 & 0.0356 & & Anoxia + Air & 0.0017 & 0.0011 & 0.297 \\
\hline Anoxia $2 \mathrm{~h}$ & 0.0173 & 0.0070 & $0.004^{\star \star}$ & $\mathrm{CoCl}_{2} 2 \mathrm{~h}$ & 0.9576 & 0.1652 & $<0.001^{\star \star \star}$ & Anoxia $6 \mathrm{~h}$ & 0.1505 & 0.0374 & $0.020^{\star}$ \\
\hline Anoxia $4 \mathrm{~h}$ & 0.0458 & 0.0255 & $0.024^{*}$ & $\mathrm{CoCl}_{2} 4 \mathrm{~h}$ & 1.0009 & 0.0931 & $<0.001^{\star \star \star}$ & Anoxia + RBCs & 0.0062 & 0.0006 & 0.061 \\
\hline Anoxia $6 \mathrm{~h}$ & 0.0150 & 0.0078 & 0.146 & $\mathrm{CoCl}_{2} 6 \mathrm{~h}$ & 0.4786 & 0.1036 & $0.005^{\star *}$ & Anoxia + RBCs deox & 0.0398 & 0.0169 & $0.026^{*}$ \\
\hline Anoxia 24 h & 0.0199 & 0.0084 & $0.004^{\star \star}$ & $\mathrm{CoCl}_{2} 24 \mathrm{~h}$ & 0.2218 & 0.0652 & 0.112 & $\mathrm{CoCl}_{2}$ & 0.8187 & 0.2710 & $0.035^{*}$ \\
\hline
\end{tabular}

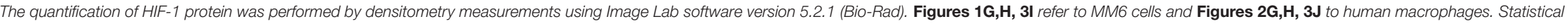
analyses were performed with Past 3 Software, using ANOVA method for data of Figures $\mathbf{1 G}, \mathbf{H}, \mathbf{2} \mathbf{G}, \mathbf{H}$ and paired student's T-test for Figures 31,J. A.U., arbitrary units.

${ }^{*} p<0.05$.

${ }^{* *} p<0.01$.

${ }^{* *} p<0.001$. 
A

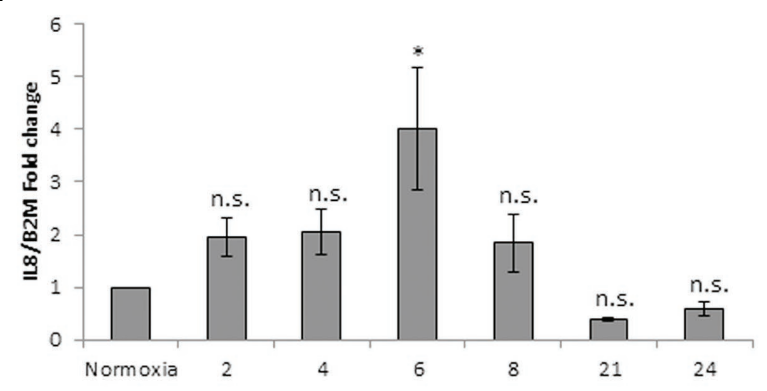

B

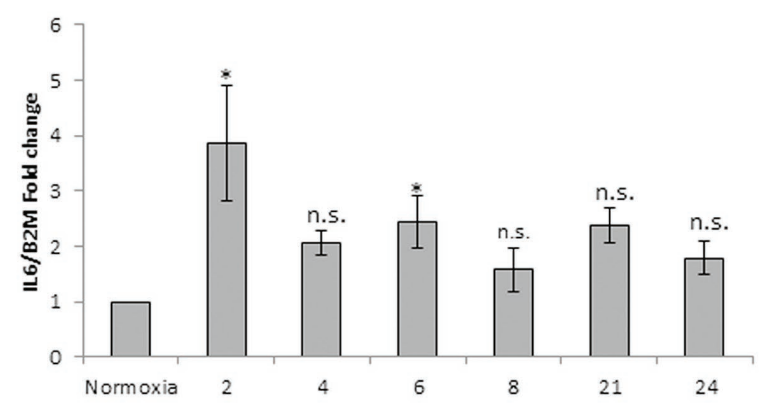

C

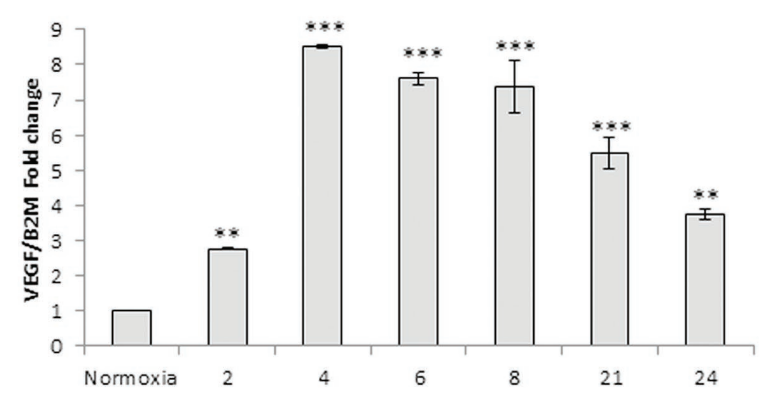

G

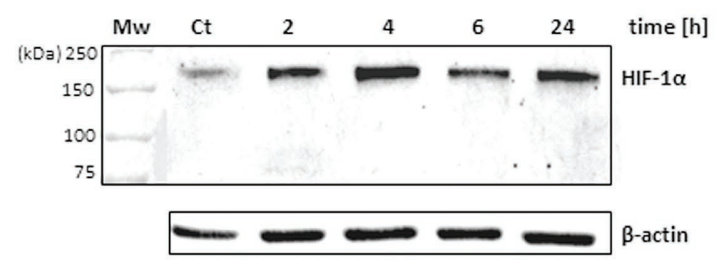

D

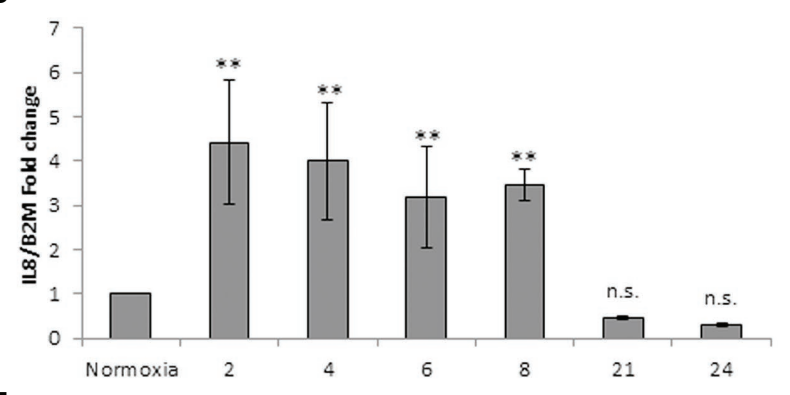

E

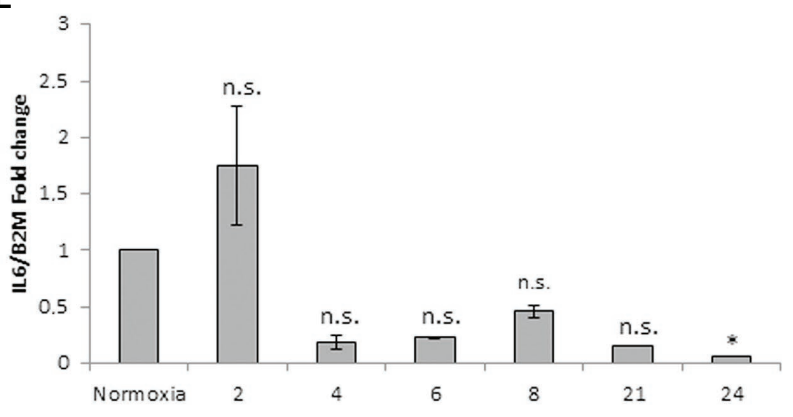

F

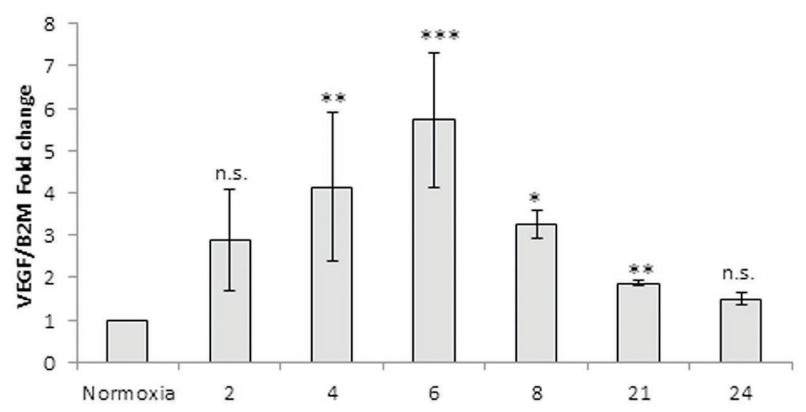

H

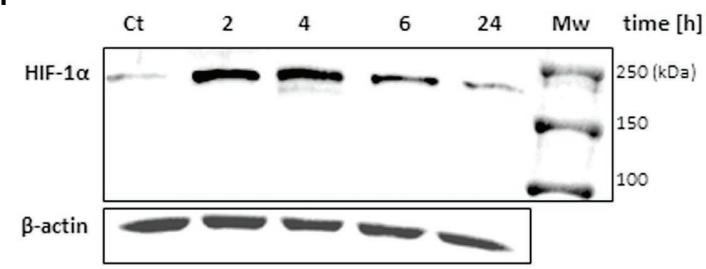

FIGURE 2 | mRNA levels of IL-8, IL-6 and VEGF in cell extracts of human macrophages from peripheral blood after anoxia (95\% $\mathrm{N}_{2}, 5 \% \mathrm{CO}$; A-C) and $100 \mu \mathrm{M}$ $\mathrm{CoCl}_{2}$ (D-F) treatment at different times (hours). Values are expressed as mean $\pm \mathrm{SD} ; n=3,{ }^{*} p<0.05 ;{ }^{* *} p<0.01$; ${ }^{* * *} p<0.001$; n.s. not significant. Western blotting analysis shows the HIF-1 $\alpha$ protein in total extracts after anoxia $\mathbf{( G )}$ and $\mathrm{CoCl}_{2} \mathbf{( H )}$ treatment of human macrophages at the indicated times.

$14.08 \pm 2.93, p=0.047)$, Figure 3A. Interestingly, Figure 3I that relates to western blot analysis of the same cell samples, shows a strong decrease of HIF- $1 \alpha$ band protein when anoxic MM6 cells are treated with native RBCs (lane 3), similarly to reoxygenated MM6 cells (lane 5), while the protein band is evident after $21 \mathrm{~h}$ anoxia exposure (lane 2) or after $100 \mu \mathrm{M}$ $\mathrm{CoCl}_{2}$ treatment (lane 6), as expected. The administration of deoxygenated RBCs to anoxic MM6 cells does not seem to lead to the same result, since HIF- $1 \alpha$ protein band is maintained (lane 4). Densitometric analysis of Figure 3I has been reported in Table 1. In Figure 3I the blot of lamin protein as control protein was reported in addition to actin, in order to show that the protein content derived only from MM6 cells and not from RBCs. Figure 3 shows in similar way the levels of IL-8, IL-6, TNF $\alpha$ and VEGF mRNA expression in human macrophages as response to the same stimuli; IL- 8 mRNA level appears to increase in anoxic cells treated with native RBCs (anoxia $6 \mathrm{~h}+\mathrm{RBCs}, 3.62 \pm 0.11$-folds vs. anoxia $6 \mathrm{~h}$, 
A

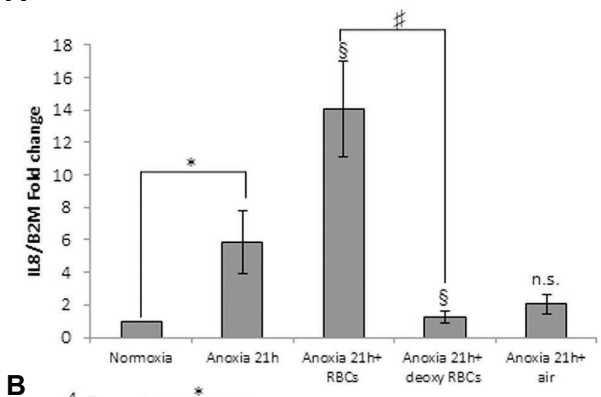

B

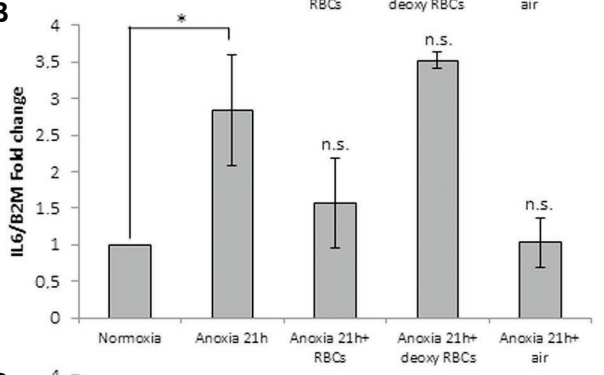

C

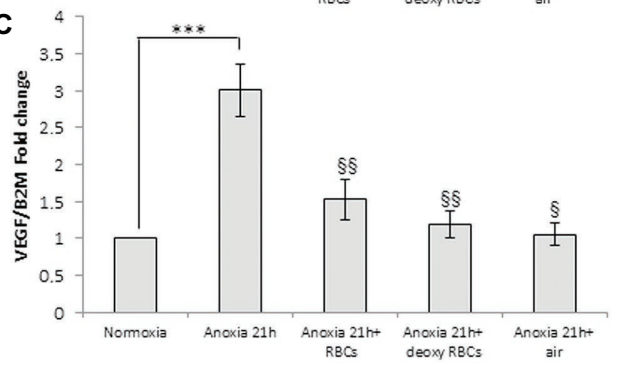

E

F
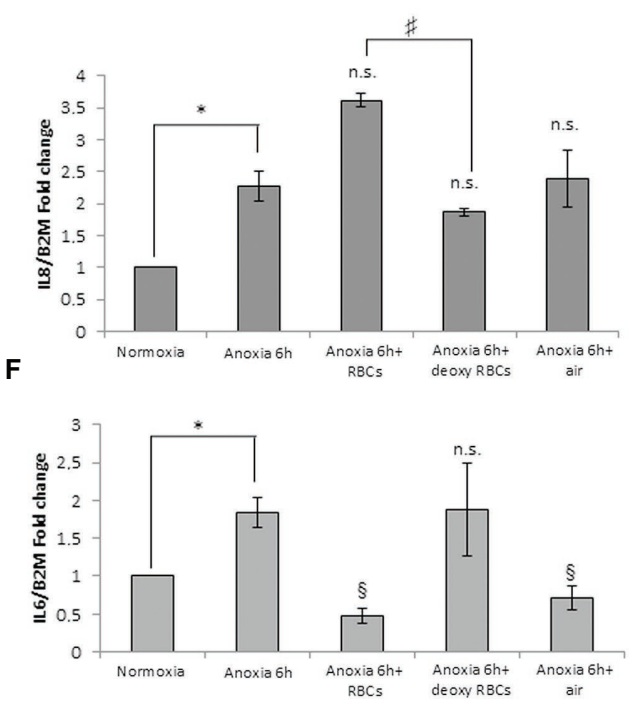

G

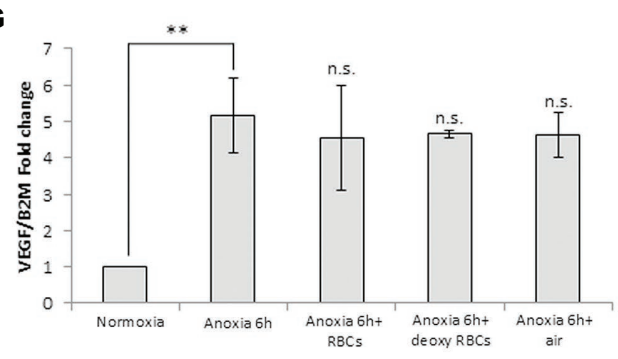

H

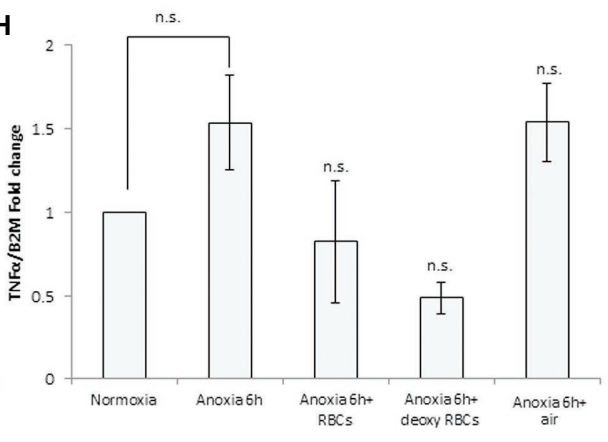

J

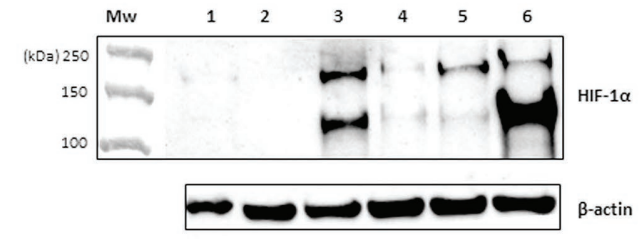

FIGURE 3 | mRNA levels of IL-8, IL-6, VEGF and TNF $\alpha$ in cell extracts of MM6 cells (A-D) and human macrophages (E-H) after the incubation with red blood cells (RBCs; $10 \% \mathrm{Ht}$ ) deoxygenated or not. Values are expressed as mean $\pm \mathrm{SD} ; n=3 ;{ }^{*} p<0.05,{ }^{* *} p<0.01,{ }^{* * *} p<0.001$ when compared with normoxic samples. ${ }^{s} p<0.05,{ }^{s \S} p<0.01$ when compared with anoxic samples. ${ }^{*} p<0.05$ when anoxia + RBCs samples were compared with anoxia + deoxy RBCs samples. Western blotting analysis shows the HIF-1 $\alpha$ protein in total extracts of MM6 cells (I, 1. Control 2. Anoxia $21 \mathrm{~h} 3$. Anoxia $21 \mathrm{~h}+\mathrm{RBCs} 3 \mathrm{~h} 4$. Anoxia $21 \mathrm{~h}+$ deoxy RBCs $3 \mathrm{~h} 5$. Anoxia $21 \mathrm{~h}+$ air $3 \mathrm{~h}$; and 6. $100 \mu \mathrm{M} \mathrm{CoCl} 21 \mathrm{~h}$ ) or human macrophages (J, 1. Control 2. Anoxia $6 \mathrm{~h}+$ air $3 \mathrm{~h} \mathrm{3}$. Anoxia $6 \mathrm{~h} \mathrm{4.} \mathrm{Anoxia} 6 \mathrm{~h}+\mathrm{RBCs} 3 \mathrm{~h} 5$. Anoxia $6 \mathrm{~h}+$ deoxy RBCs $3 \mathrm{~h}$; and 6. $\left.100 \mu \mathrm{M} \mathrm{CoCl}_{2} 6 \mathrm{~h}\right)$ after incubation with RBCs $(10 \% \mathrm{Ht})$ deoxygenated or not. 
$2.27 \pm 0.24, p=0.61$, Figure 3E) whereas IL-6 levels significantly decrease (anoxia $6 \mathrm{~h}+\mathrm{RBCs} 0.47 \pm 0.10$-folds vs. $1.84 \pm 0.20$, $p=0.045$; Figure 3F). Moreover, VEGF mRNA levels do not seem to change $(4.54 \pm 1.43$ vs. $5.16 \pm 1.04, p=0.56)$, Figure 3G. On the contrary, the treatment with deoxy RBCs results in the expression levels of the target genes which do not differ from those found in the cells exposed to only anoxia. In fact, no significant increase of neither IL-8 (Figure 3E) nor VEGF (Figure 3G) mRNA values were found respect to those found in the anoxic cells (for IL-8; anoxia $6 \mathrm{~h}+$ deoxy $\mathrm{RBC}, 1.87 \pm 0.06$ vs. anoxia $6 \mathrm{~h} 2.27 \pm 0.24, p=0.29$; for VEGF; $4.65 \pm 0.10$ vs. anoxia 6 h $5.16 \pm 1.04, p=0.26$ ). Moreover, IL-6 mRNA expression after anoxia exposure (Figure 3F) significantly decreases after the re-oxygenation of cells, and it does not change after incubation with deoxy RBCs (anoxia $6 \mathrm{~h}+$ air $0.71 \pm 0.16$ and anoxia $6 \mathrm{~h}+$ deoxy RBCs $1.87 \pm 0.62$ vs. anoxia $6 \mathrm{~h} 1.84 \pm 0.20$, with $p=0.013$ and $p=0.88$, respectively). In addition, the increase of IL- 8 mRNA value (Figure 3E) after administration of native RBCs is significantly different respect to value obtained with deoxy RBCs (anoxia $6 \mathrm{~h}+\mathrm{RBCs} 3.62 \pm 0.11$ vs. anoxia $6 \mathrm{~h}+\mathrm{RBC}$ deoxy $1.87 \pm 0.06, p=0.042$ ). Furthermore, it appears that anoxia treatment leads to slight increase of TNF $\alpha$ mRNA levels in both MM6 (1.29 \pm 0.18 -fold) and human macrophages $(1.54 \pm 0.28$-fold $)$ respectively, Figures $3 \mathrm{D}, \mathrm{H}$. Moreover, the administration of native RBCs seems to further significantly increase these values $(2.34 \pm 0.17$-fold, $p=0.042)$ in anoxic MM6 cells, while the ddeoxy RBCs do not (1.32 \pm 0.57 -fold, $p=0.756$ ), Figure 3D. Instead, the treatments with both native and deoxy RBCs to anoxic human macrophages leads to a not significant decrease of TNF $\alpha$ expression levels $(0.82 \pm 0.36$ fold and $0.48 \pm 0.09$-fold, respectively), Figure $3 \mathrm{H}$. Although increased levels of TNF $\alpha$ mRNA after RBCs treatment were evidenced, they did not reach values obtained for IL-8 cytokine; however, the data could be interesting considering that it is known that TNF $\alpha$ is the principal cytokine driving the adhesion of MM6 cells to endhotelial cells as already reported (Schuettpelz and Link, 2013; Poussin et al., 2014). The Supplementary Tables 1, 2 report the RTqPCR data of Figure 3.

Figure 3J, showing analysis of HIF-1 $\alpha$ protein in human macrophage samples, evidences a response to these treatments similar to MM6 cells. In fact, the incubation of macrophages exposed $6 \mathrm{~h}$ to anoxia with native RBCs leads to the disappearance of HIF- $1 \alpha$ in total cell extracts (lane 4) and this partially occurs with the deoxy RBCs (lane 5). Densitometric analysis of Figure $3 \mathbf{J}$ has been reported in Table 1. The presence of different HIF- $1 \alpha$ protein isoforms revealed by western blotting analysis (Figures 1G, H; Figures 2G,H; Figures 3I,J) could be explained by their possible post-translational modifications. It is not unusual to find in literature several articles concerning the presence of a broad range of HIF- $1 \alpha$ isoforms, commonly reported in both healthy and tumor cells (Monsef et al., 2010). Several studies report on HIF- $1 \alpha$ isoforms lacking several exons than the wild type full length isoform. Some of these isoforms encode cytoplasmic HIF- $1 \alpha$ protein or proteins with altered transcriptional activity compared to the wild type protein (Gothié et al., 2000; Chun et al., 2001, 2002; Depping et al., 2004; Lukashev and Sitkovsky, 2008). Different HIF-1 $\alpha$ isoforms, such as HIF-1 $\alpha 1.2$ which is 59 amino acids shorter (86 $\mathrm{KDa})$ than wild type HIF- $1 \alpha$ (93 KDa; Depping et al., 2004), HIF1 $\alpha 1.3$ which encodes a functional protein of $95 \mathrm{KDa}$ (Lukashev and Sitkovsky, 2008), and isoforms lacking either exon $12(62 \mathrm{KDa})$ or exon $14(82 \mathrm{KDa}$; Gothié et al., 2000; Chun et al., 2001) or exons 11 and 12 (58 KDa; Chun et al., 2002) were found. Importantly, the anti-HIF- $1 \alpha$ antibody used in our analyses can recognize also the HIF- $1 \alpha$ protein isoforms codified by the alternative splicing variants that act as dominant negative HIF-1 $\alpha$ isoforms (Chun et al., 2001, 2002), which are able to inhibit the activity of wild type full length HIF-1 $\alpha$. The different molecular weights showed by our immunoblots could be explained by both alternative splicing events or by different post-translational modifications including phosphorylation, S-nitrosylation and acetylation (Toffoli et al., 2007; Geng et al., 2012; Sanhueza et al., 2020). Moreover, the dimeric protein that appears at a position of approximately $200 \mathrm{kDa}$ could be explained by the presence of HIF-1 $\alpha$ complexed with other proteins or factors (e.g., the constitutively expressed HIF-1 $\beta$-subunit, or enzymes such as VHL).

Our data indicate that RBCs could up-regulate IL-8 mRNA and down-regulate IL- 6 mRNA and VEGF mRNA expression in a way that is independent of HIF- $1 \alpha$ in human macrophages in anoxic condition; similarly, this occurs also for the human monocytic MM6 cells that respond also with an increased $\mathrm{TNF} \alpha$ mRNA expression.

Moreover, we investigated if the expression of HIF-1 $\alpha$ mRNA levels could be changed in anoxic MM6 and macrophage cells treated with RBCs to provide another way supporting the not involvement of HIF- $1 \alpha$ in the up-regulation of IL-8. These results are reported in Supplementary Figure 1, showing a decrease of HIF-1 $\alpha$ mRNA levels in cell extracts of human MM6 and macrophage anoxic cells treated with native and deoxygenated RBCs; specifically, for MM6 cells $0.57 \pm 0.29$ fold ( $p=0.157$, Supplementary Figure 1A) and for macrophages $0.75 \pm 0.14$-fold ( $p=0.115$, Supplementary Figure 1B) when native human RBCs were administered. When deoxygenated RBCs were administered to MM6 cells, $0.79 \pm 0.12$-fold $(p=0.102$, Supplementary Figure 1A) and to human macrophages $0.84 \pm 0.21$-fold $(p=0.295$, Supplementary Figure 1B) were found. Thus, HIF- $1 \alpha$ mRNA levels were not significantly different when compared with levels of anoxic cells (MM6 cells $0.62 \pm 0.21$-fold, Supplementary Figure 1A; human macrophages $0.78 \pm 0.05$ fold, Supplementary Figure 1B). Since both HIF- $1 \alpha$ mRNA and corresponding protein levels decrease in cells treated with native RBCs, we can hypothesize that HIF- $1 \alpha$ transcription factor could not be directly involved in the increase of IL- 8 expression levels. In literature, some works reported evidences that link the upregulation of IL- 8 with the increased recruitment of some transcriptional factors binding IL- 8 promoter, like Egr-1 (Singha et al., 2014). Probably, the different expression peaks of IL- 8 mRNA in MM6 (21 h) and macrophage cells $(6 \mathrm{~h})$ could be explained by the fact that Egr-1 or other 
transcription factors accumulate early in macrophages after exposure to hypoxic/anoxic conditions and lately in monocytic leukemia cells (Elbarghati et al., 2008).

We think that RBCs, as modulator of $\mathrm{pO}_{2}$, could interact with these cell systems through mechanisms that would be interesting to study.

Since our data indicate that native RBCs administrated to monocyte-macrophage cell lines induce a specific modulation of IL-8 mRNA expression, it could be useful to understand which are the transcription factors on which these specific cellular responses depend. This aspect is important considering the putative role that this interleukin plays in vascular niche of BM. It was shown that, as other soluble factors, the IL-8 has a pleiotropic role and affects, directly or indirectly, different cellular pathways such as hematopoietic differentiation, cell survival and angiogenesis (Dudek et al., 2003; Aronovich et al., 2013; Poulos et al., 2013). On the other hand, it is known that the maturation of RBCs involves some interactions with macrophages, first during their development in the BM, later in the blood stream with macrophages found in the liver and spleen. These interactions are essential to maintain $\mathrm{RBC}$ homeostasis or to ensure the correct removal of aged or damaged RBCs. Our studies could aid to reveal how some biological factors, derived from macrophage and $\mathrm{RBC}$ interactions, play a role in $\mathrm{BM}$ vascular niche. Considering that contacts take place between macrophage and erythroblastic islands and that erythrocytic cells are capable of migrating toward BM sinusoids as erythroid precursors, it is also reasonable to think that the $\mathrm{RBC}$-macrophages interactions can affect or regulate the function of the other cell components in bone vascular niche, such as megakaryocytic cells associated with the BM vasculature (Machlus and Italiano, 2013). Several researchers are attempting to clarify these aspects studying the dynamic interactions between cellular and molecular components of the BM vascular niche (Zhang et al., 2019); co-culture cell models, where different cells types (for example erythrocytes, macrophages, megakaryocytes and endothelial cells) coexist together, represent versatile tools for investigating these cellular interactions. For example, the biocompatible bioengineered tissue-models, such as 3D BM device mimicking the different features of the BM environment (Di Buduo et al., 2015; Abbonante et al., 2020) are promising approaches to study megakaryocyte function; once in contact with the biomaterial, megakaryocytes extend proplatelets into the perfused culture medium, mimicking blood shear stress. Therefore, the possibility to take advantage of this perfusion bioreactor chamber mimicking ex vivo the vascular niche, will allow to transfer in a $3 \mathrm{D}$ cell model the results herein reported in order to better understand how the RBCs can influence the intercellular cross-talk in the vascular niche.

\section{CONCLUSION}

Herein, we investigated the modulation of mRNA expression of few key cytokines (IL-6, IL-8, VEGF, and TNF $\alpha$ ) and the possible role of HIF- $1 \alpha$ transcription factor, in the early response to the stimuli considered in our experimental cell model; the data indicated the not involvement of HIF- $1 \alpha$ in the regulation of these specific cytokines. HIF-1 independent cellular pathways have been reported in solid tumor such as the glioblastoma (Tardòn et al., 2020). Other mechanisms that do not involve HIF- $1 \alpha$ have already been described, thus elucidating a novel HIF-independent point of control of cellular metabolism, energetics, and post-transcriptional gene regulations by $\mathrm{O}_{2}$, such as mTOR inactivation, or the activation of NF-kB through reactive oxygen species (ROS; Arsham et al., 2003; Mizukami et al., 2005, 2007; Lluis et al., 2007; Park et al., 2012). We can speculate that the treatment of anoxic cells with RBCs leads to a remarkable decrease of HIF- $1 \alpha$, which acts as a repressor of IL-8 (Loboda et al., 2012). This point would explain the observed increase of IL- 8 mRNA levels. Furthermore, it was evidenced that, in a model of human glioblastoma, the hypoxiainduced accumulation of HIF-1 $\alpha$ was correlated with an increase of IL-6 levels (Xue et al., 2016). Therefore, in our cell model the RBC-mediated decrease of HIF- $1 \alpha$ could explain the decrease of IL-6 mRNA levels. Other factors such as HIF- $2 \alpha$, HIF- $3 \alpha$, AP-1, C/EBP and NF-kB may play a role in hypoxia (Shih and Claffey, 1998; Hirani et al., 2001; Rius et al., 2008; Palazon et al., 2014), while ATF-4 and Egr-1 are hypoxia responsive factors in macrophages, but only after early exposures (Elbarghati et al., 2008). In conclusion, a number of transcription factors work together in a tightly regulated fashion to control macrophage activities in hypoxic condition. Further studies are necessary to examine the role of those players under the experimental conditions investigated.

\section{DATA AVAILABILITY STATEMENT}

The authors acknowledge that the data presented in this study must be deposited and made publicly available in an acceptable repository, prior to publication. Frontiers cannot accept a manuscript that does not adhere to our open data policies.

\section{ETHICS STATEMENT}

The authors state that they have obtained appropriate institutional review board approval or have followed the principles outlined in the Declaration of Helsinki for all human experimental investigations. In addition, for investigations involving the use of human blood, an informed consent has been obtained from the subjects involved, on the basis of official document of accordance with the Transfusion Center of "S. Maria della Misericordia" Hospital in Urbino (PU), Italy.

\section{AUTHOR CONTRIBUTIONS}

AA and MM defined the study and planned the experiments. AA and ES performed experiments and data acquisition and analysis. AA wrote the manuscript. MM revised the manuscript. All authors contributed to the article and approved the submitted version. 


\section{FUNDING}

This work was supported by PRIN (PROGETTI DI RICERCA DI RILEVANTE INTERESSE NAZIONALE - Bando 2017; Prot. 2017Z5LR5Z).

\section{REFERENCES}

Abbonante, V., Di Buduo, C. A., Malara, A., Laurent, P. A., and Balduini, A. (2020). Mechanisms of platelet release: in vivo studies and in vitro modeling. Platelets 31, 717-723. doi: 10.1080/09537104.2020.1774532

Antonelli, A., Szwargulski, P., Scarpa, E. S., Thieben, F., Cordula, G., Ambrosi, G., et al. (2020). Development of long circulating magnetic particle imaging tracers: use of novel magnetic nanoparticles and entrapment into human erythrocytes. Nanomedicine 15, 739-753. doi: 10.2217/nnm-2019-0449

Aronovich, A., Nur, Y., Shezen, E., Rosen, C., Klionsky, Y. Z., Milman, I., et al. (2013). A novel role for factor VIII and thrombin/PAR1 in regulating hematopoiesis and its interplay with the bone structure. Blood 122, 2562-2571. doi: 10.1182/blood-2012-08-447458

Arsham, A. M., Howell, J. J., and Simon, M. C. (2003). A novel hypoxiainducible factor-independent hypoxic response regulating mammalian target of Rapamycin and its targets. J. Biol. Chem. 278, 29655-29660. doi: 10.1074/ jbc.M212770200

Bauer, I., Grozio, A., Lasigliè, D., Basile, G., Sturla, L., Magnone, M., et al. (2012). The $\mathrm{NAD}^{+}$-dependent histone deacetylase SIRT6 promotes cytokine production and migration in pancreatic cancer cells by regulating $\mathrm{Ca}^{2+}$ responses. J. Biol. Chem. 288, 40924-40937. doi: 10.1074/jbc.M112.405837

Chow, D. C., Wenning, L. A., Miller, W. M., and Papoutsakis, E. T. (2001). Modeling $\mathrm{pO}_{2}$ distributions in the bone marrow hematopoietic compartment. I. Krogh's model. Biophys. J. 81, 675-684. doi: 10.1016/ S0006-3495(01)75732-3

Chun, Y. S., Choi, E., Kim, T. Y., Kim, M. S., and Park, J. W. (2002). A dominant-negative isoform lacking exons 11 and 12 of the human hypoxiainducible factor-1alpha gene. Biochem. J. 362, 71-79. doi: 10.1042/ 0264-6021:3620071

Chun, Y. S., Choi, E., Yeo, E. J., Lee, J. H., Kim, M. S., and Park, J. W. (2001). A new HIF-1 alpha variant induced by zinc ion suppresses HIF-1-mediated hypoxic responses. J. Cell Sci. 114, 4051-4061.

D’Atri, L. P., Pozner, R. G., Nahmod, K. A., Landoni, V. I., Isturiz, M., Negrotto, S., et al. (2011). Paracrine regulation of megakaryo/thrombopoiesis by macrophages. Exp. Hematol. 39, 763-772. doi: 10.1016/j.exphem.2011.03.009

Depping, R., Hägele, S., Wagner, K. F., Wiesner, R. J., Camenisch, G., Wenger, R. H., et al. (2004). A dominant-negative isoform of hypoxia-inducible factor-1 alpha specifically expressed in human testis. Biol. Reprod. 71, 331-339. doi: 10.1095/biolreprod.104.027797

Di Buduo, C. A., Wray, L. S., Tozzi, L., Malara, A., Chen, Y., Ghezzi, C. E., et al. (2015). Programmable 3D silk bone marrow niche for platelet generation ex vivo and modeling of megakaryopoiesis pathologies. Blood 125, 2254-2264. doi: 10.1182/blood-2014-08-595561

Di Girolamo, M., Fabrizio, G., Scarpa, E. S., and Di Paola, S. (2013). NAD ${ }^{+}$ dependent enzymes at the endoplasmic reticulum. Curr. Top. Med. Chem. 13, 3001-3010. doi: 10.2174/15680266113136660214

Dudek, A. Z., Nesmelova, I., Mayo, K., Verfaillie, C. M., Pitchford, S., and Slungaard, A. (2003). Platelet factor 4 promotes adhesion of hematopoietic progenitor cells and binds IL-8: novel mechanisms for modulation of hematopoiesis. Blood 101, 4687-4694. doi: 10.1182/blood-2002-08-2363

Edatt, L., Poyyakkara, A., Raji, G. R., Ramachandran, V., Shankar, S. S., and Kumar, S. V. B. (2020). Role of sirtuins in tumor angiogenesis. Front. Oncol. 9:1516. doi: 10.3389/fonc.2019.01516

Elbarghati, L., Murdoch, C., and Lewis, C. E. (2008). Effects of hypoxia on transcription factor expression in human monocytes and macrophages. Immunobiology 213, 899-908. doi: 10.1016/j.imbio.2008.07.016

Fang, H. Y., Hughes, R., Murdoch, C., Coffelt, S. B., Biswas, S. K., Harris, A. L., et al. (2009). Hypoxia-inducible factors 1 and 2 are important transcriptional effectors in primary macrophages experiencing hypoxia. Blood 114, 4-33. doi: 10.1182/blood-2008-12-195941

\section{SUPPLEMENTARY MATERIAL}

The Supplementary Material for this article can be found online at: https://www.frontiersin.org/articles/10.3389/fphys.2021.632682/ full\#supplementary-material

Geng, H., Liu, Q., Xue, C., David, L. L., Berer, T. M., Thomas, G. V., et al. (2012). HIF1 protein stability is increased by acetylation at lysine 709 . J. Biol. Chem. 287, 35496-35505. doi: 10.1074/jbc.M112.400697

Gothié, E., Richard, D. E., Berra, E., Pagès, G., and Pouyssegur, J. (2000). Identification of alternative spliced variants of human hypoxia-inducible factor-1alpha. J. Biol. Chem. 275, 6922-6927. doi: 10.1074/jbc.275.10.6922

Hirani, N., Antonicelli, F., Strieter, R. M., Wiesener, M. S., Ratcliffe, P. J., Haslett, C., et al. (2001). The regulation of Interleukin- 8 by hypoxia in human macrophages-a potential role in the pathogenesis of the acute respiratory distress syndrome (ARDS). Mol. Med. 7, 685-697.

Huang, L. E., Gu, J., Schau, M., and Bunn, H. F. (1998). Regulation of hypoxiainducible factor lalpha is mediated by an O2-dependent degradation domain via the ubiquitin-proteasome pathway. Proc. Natl. Acad. Sci. U. S. A. 95, 7987-7992.

Lluis, J. M., Buricchi, F., Chiarugi, P., Morales, A., and Fernandez-Checa, J. C. (2007). Dual role of mitochondrial reactive oxygen species in hypoxia signaling: activation of nuclear factor-\{kappa\}B via c-SRC and oxidant-dependent cell death. Cancer Res. 67, 7368-7377. doi: 10.1158/0008-5472.CAN-07-0515

Loboda, A., Jozkowicz, A., and Dulak, J. (2012). HIF-1 versus HIF-2 - is one more important than the other? Vasc. Pharmacol. 56, 245-251. doi: 10.1016/j. vph.2012.02.006

Lukashev, D., and Sitkovsky, M. (2008). Preferential expression of the novel alternative isoform I.3 of hypoxia-inducible factor lalpha in activated human T lymphocytes. Hum. Immunol. 69, 421-425. doi: 10.1016/j.humimm. 2008.05.004

Machlus, K. R., and Italiano, J. J. E. (2013). The incredible journey: from megakaryocyte development to platelet formation. J. Cell Biol. 201, 785-796. doi: $10.1083 /$ jcb.201304054

Magnani, M., Crinelli, R., Antonelli, A., Casabianca, A., and Serafini, G. (1994). The soluble but not mitochondrially bound hexokinase is a substrate for the ATP- and ubiquitin-dependent proteolytic system. Biochim. Biophys. Acta 1206, 180-190.

Metinko, A. P., Kunkel, S. L., Standiford, T. J., and Strieter, R. M. (1992). Anoxia-Hyperoxia induces monocyte-derived Interleukin-8. J. Clin. Invest. 90, 791-798.

Mizukami, Y., Jo, W. S., Duerr, E. M., Gala, M., Li, J., Zhang, X., et al. (2005) Induction of interleukin-8 preserves the angiogenic response in HIF-1alphadeficient colon cancer cells. Nat. Med. 11, 992-997. doi: 10.1038/nm1294

Mizukami, Y., Kohgo, Y., and Chung, D. C. (2007). Hypoxia inducible Factor-1 independent pathways in tumor angiogenesis. Clin. Cancer Res. 13, 5670-5674. doi: 10.1158/1078-0432.CCR-07-0111

Monsef, M., Soller, M., Panagopoulos, I., and Abrahamsson, P. A. (2010). HIF1 $\alpha$ isoforms in benign and malignant prostate tissue and their correlation to neuroendocrine differentiation. BMC Cancer 10:385. doi: 10.1186/ 1471-2407-10-385

Morrison, S. J., and Scadden, D. T. (2014). The bone marrow niche for haematopoietic stem cells. Nature 505, 327-334. doi: 10.1038/nature12984

Munoz-Sànchez, J., and Chanez-Càrdenas, M. (2019). The use of cobalt chloride as a chemical hypoxia model. J. Appl. Toxicol. 39, 556-570. doi: 10.1002/ jat.3749

Murdoch, C., Muthana, M., and Lewis, C. E. (2005). Hypoxia regulates macrophage functions in inflammation. J. Immunol. 175, 6257-6263. doi: 10.4049/ jimmunol.175.10.6257

Palazon, A., Goldrath, A. W., Nizet, V., and Johnson, R. S. (2014). HIF transcription factors, inflammation, and immunity. Immunity 41, 518-528. doi: 10.1016/j.immuni.2014.09.008

Palma, L., Sfara, C., Antonelli, A., and Magnani, M. (2011). Pharmacology, dexamethasone restrains ongoing expression of interleukin-23p19 in peripheral blood-derived human macrophages. BMC Pharmacol. 11:8. doi: 10.1186/ 1471-2210-11-8 
Park, E. C., Ghose, P., Shao, Z., Ye, Q., Kang, L., Xu, X. Z. S., et al. (2012). Hypoxia regulates glutamate receptor trafficking through an HIF-independent mechanism. EMBO J. 31, 1379-1393. doi: 10.1038/emboj.2011.499

Parmar, K., Mauch, P., Vergilio, J. A., Sackstein, R., and Down, J. D. (2007). Distribution of hematopoietic stem cells in the bone marrow according to regional hypoxia. PNAS 104, 5431-5436. doi: 10.1073/pnas.0701152104

Poulos, M. G., Guo, P., Kofler, N. M., Pinho, S., Gutkin, M. C., Tikhonova, A., et al. (2013). Endothelial Jagged-1 is necessary for homeostatic and regenerative hematopoiesis. Cell Rep. 4, 1022-1034. doi: 10.1016/j.celrep.2013.07.048

Poussin, C., Gallitz, I., Schlage, W. K., Steffen, Y., Stolle, K., Lebrun, S., et al. (2014). Mechanism of an indirect effect of aqueous cigarette smoke extract on the adhesion of monocytic cells to endothelial cells in an in vitro assay revealed by transcriptomics analysis. Toxicol. In Vitro 28, 896-908. doi: 10.1016/j.tiv.2014.03.005

Rana, N. K., Singh, P., and Koch, B. (2019). $\mathrm{CoCl}_{2}$ simulated hypoxia induce cell proliferation and alter the expression pattern of hypoxia associated genes involved in angiogenesis and apoptosis. Biol. Res. 52, 12-24. doi: 10.1186/s40659-019-0221-z

Richter, R., Forssmann, W., and Henschler, R. (2017). Current developments in mobilization of hematopoietic stem and progenitor cells and their interaction with niches in bone marrow. Transfus. Med. Hemother. 44, 151-164. doi: $10.1159 / 000477262$

Rius, J., Guma, M., Schachtrup, C., Akassoglou, K., Zinkernagel, A. S., Nizet, V., et al. (2008). NF-kappaB links innate immunity to the hypoxic response through transcriptional regulation of HIF-1alpha. Nature 453, 807-811. doi: 10.1038/nature06905

Rydberg, E. K., Salomonsson, L., Hulten, L. M., Noren, K., Bondjers, G., Wiklund, O., et al. (2003). Hypoxia increases 25-hydroxycholesterol-induced interleukin-8 protein secretion in human macrophages. Atherosclerosis 170, 245-252. doi: 10.1016/s0021-9150(03)00302-2

Sanhueza, C., Bennett, J. C., Valenzuela-Valderrama, M., Contreras, P., Lobos-Gonzalez, L., Campos, A., et al. (2020). Caveolin-1-mediated tumor suppression is linked to reduced HIF1 $\alpha$ S-Nitrosylation and transcriptional activity in hypoxia. Cancers 12, 2349-2366. doi: 10.3390/cancers12092349

Scarpa, E. S., Tasini, F., Crinelli, R., Ceccarini, C., Magnani, M., and Bianchi, M. (2020). The ubiquitin gene expression pattern and sensitivity to UBB and UBC knockdown differentiate primary 23132/87 and metastatic MKN45 gastric cancer cells. Int. J. Mol. Sci. 21, 5435-5453. doi: 10.3390/ijms21155435

Schuettpelz, L. G., and Link, D. C. (2013). Regulation of hematopoietic stem cell activity by inflammation. Front. Immunol. 4:204. doi: 10.3389/fimmu.2013.00204

Shih, S. C., and Claffey, K. P. (1998). Hypoxia-mediated regulation of gene expression in mammalian cells. Int. J. Exp. Pathol. 79, 347-357.

Singha, B., Gatla, H. R., Manna, S., Chang, T. P., Sanacora, S., Poltoratsky, V., et al. (2014). Proteasome inhibition increases recruitment of IkB kinase B (IKKB), S536P-p65, and transcription factor EGR1 to interleukin-8 (IL-8) promoter, resulting in increased IL-8 production in ovarian cancer cells. $J$. Biol. Chem. 289, 2687-2700. doi: 10.1074/jbc.M113.502641

Spencer, J. A., Ferraro, F., Roussakis, E., Klein, A., Wu, J., Runnels, J. M., et al. (2014). Direct measurement of local oxygen concentration in the bone marrow of live animals. Nature 508, 269-273. doi: 10.1038/nature13034
Tamma, R., and Ribatti, D. (2017). Bone niches, hematopoietic stem cells, and vessel formation. Int. J. Mol. Sci. 18, 151-163. doi: 10.3390/ ijms18010151

Tamura, R., Tanaka, T., Akasaki, Y., Murayama, Y., Yoshida, K., and Sasaki, H. (2020). The role of vascular endothelial growth factor in the hypoxic and immunosuppressive tumor microenvironment: perspectives for therapeutic implications. Med. Oncol. 37, 2-15. doi: 10.1007/s12032-019-1329-2

Tanaka, T., Narazaki, M., and Kishimoto, T. (2014). IL-6 in inflammation, immunity, and disease. Cold Spring Harb. Perspect. Biol. 6:a016295. doi: 10.1101/cshperspect.a016295

Tardòn, M. C., Marinari, E., Migliorini, D., Bes, V., Tankov, S., Charrier, E. et al. (2020). An experimentally defined hypoxia gene signature in glioblastoma and its modulation by metformin. Biology 9, 264-280. doi: 10.3390/ biology9090264

Toffoli, S., Feron, O., Raes, M., and Michiels, C. (2007). Intermittent hypoxia changes HIF- $1 \alpha$ phosphorylation pattern in endothelial cells: Unravelling of a new PKA-dependent regulation of HIF-1 $\alpha$. Biochim. Biophys. Acta 1773, 1558-1571. doi: 10.1016/j.bbamcr.2007.06.002

Wang, G. L., Jiang, B. H., Rue, E. A., and Semenza, G. L. (1995). Hypoxiainducible factor 1 is a basic-helix-loop-helix-PAS heterodimer regulated by cellular O2 tension. Proc. Natl. Acad. Sci. U. S. A. 92, 5510-5514.

Xue, H., Yuan, G., Guo, X., Liu, Q., Zhang, J., Gao, X., et al. (2016). A novel tumor-promoting mechanism of IL6 and the therapeutic efficacy of tocilizumab: hypoxia-induced IL6 is a potent autophagy initiator in glioblastoma via the p-STAT3-MIR155-3p-CREBRF pathway. Autophagy 12, 1129-1152. doi: 10.1080/15548627.2016.1178446

Yuan, Y., Hilliard, G., Ferguson, T., and Millhorn, D. E. (2003). Cobalt inhibits the interaction between hypoxia inducible factor-alpha and von HippelLindau protein by direct binding to hypoxia-inducible factor-alpha. J. Biol. Chem. 278, 15911-15916. doi: 10.1074/jbc.M300463200

Zhang, P., Zhang, C., Li, J., Han, J., Liu, X., and Yang, H. (2019). The physical microenvironment of hematopoietic stem cells and its emerging roles in engineering applications. Stem Cell Res Ther. 10, 327-339. doi: 10.1186/ s13287-019-1422-7

Ziegler-Heitbrock, H. W., Thiel, E., Futterer, A., Herzog, V., Wirtz, A., and Riethmuller, G. (1988). Establishment of a human cell line mono mac 6 with characteristics of mature monocytes. Int. J. Cancer 41, 456-461. doi: $10.1002 /$ ijc. 2910410324

Conflict of Interest: The authors declare that the research was conducted in the absence of any commercial or financial relationships that could be construed as a potential conflict of interest.

Copyright (C) 2021 Antonelli, Scarpa and Magnani. This is an open-access article distributed under the terms of the Creative Commons Attribution License (CC BY). The use, distribution or reproduction in other forums is permitted, provided the original author(s) and the copyright owner(s) are credited and that the original publication in this journal is cited, in accordance with accepted academic practice. No use, distribution or reproduction is permitted which does not comply with these terms. 